\title{
WPS3403
}

\section{WHAT HAPPENS WHEN A COUNTRY DOES NOT ADJUST TO TERMS OF TRADE SHOCKS? - THE CASE OF OIL-RICH GABON}

\author{
Ali Zafar \\ World Bank AFTP 3
}

World Bank Policy Research Working Paper 3403, September 2004

The Policy Research Working Paper Series disseminates the findings of work in progress to encourage the exchange of ideas about development issues. An objective of the series is to get the findings out quickly, even if the presentations are less than fully polished. The papers carry the names of the authors and should be cited accordingly. The findings, interpretations, and conclusions expressed in this paper are entirely those of the authors. They do not necessarily represent the view of the World Bank, its Executive Directors, or the countries they represent. Policy Research Working Papers are available online at http://econ.worldbank.org.

I would like to thank Mr. Chukwuma Obidegwu (Lead Economist, AFTP3) and Mr. Bruno Boccara (Lead Economist, AFTP3) for excellent advice and comments. 


\section{SUMMARY FINDINGS}

Gabon is currently one of the richest countries in Sub-Saharan Africa, having a GDP per capita of close to $\$ 4,000$, and is characterized by a stable political climate and very rich forestry and mineral resources, as well as a small population. Oil is the key economic sector, accounting for half of GDP and more than two-thirds of revenue. Discovered in the 1970s, oil windfalls have delivered spectacular wealth and financed public expenditure over two decades. However, the oil boom has led to the Dutch disease and the shrinkage of the industrial and agricultural sectors of the economy due to the appreciation of the exchange rate and the movement of capital to the oil sector. However, with output projections suggesting that oil will be depleted within the next 10 to 15 years, there are growing pressures on the policymakers to take actions to diversify production. While Gabon's membership in the Central African economic and monetary union means that it benefits from the macroeconomic stability from a common external trade and fixed exchange rate regime pegged to the euro, it relinquishes independence in the policy response to shocks.

An analysis using a quantitative methodology to decompose responses to shocks shows that Gabon's adjustment to adverse movements in the terms and trade from 1980 to 2000 was considerably weak in terms of three performance indicators: import intensity, economic compression, and nonoil export promotion. While the economy's growth rate was respectable, Gabonese policymakers postponed adjustment by resorting to considerable borrowing during this period. While there was some decrease in import intensity from 1987 to 1990 and 1996 to 2000 as well as slight nonoil export diversification from 1996 to 2000, the government borrowed from commercial banks and donors, causing its external debt/GDP ratio to increase spectacularly from 30 percent of GDP in 1970-76 to 80 percent in 1999. In order to pay the debt service, it currently has to maintain large primary surpluses. Only since 1996 has there been significant fiscal retrenchment and a freezing of government wages. 


\section{TABLE OF CONTENTS}

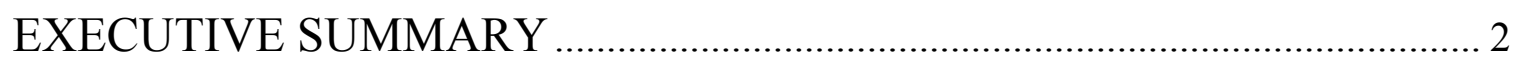

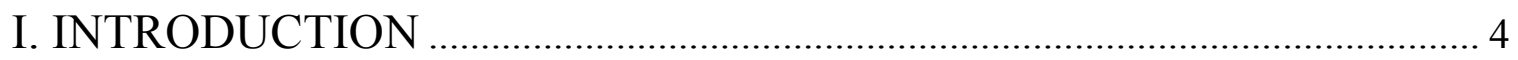

II. THEORETICAL MODEL FOR EVALUATION OF POLICY

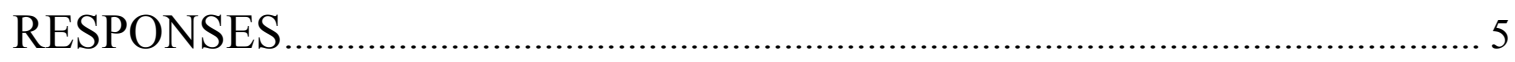

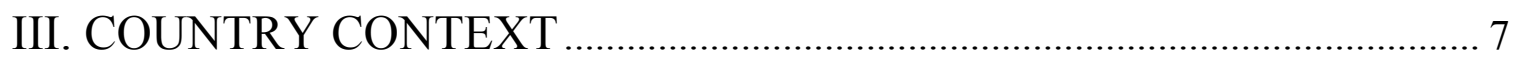

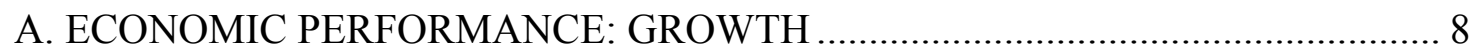

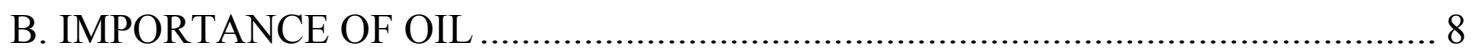

C. DUTCH DISEASE AND RENTIER STATE ................................................ 9

D. REGIONAL CONTEXT: CEMAC MEMBER …….......................................... 10

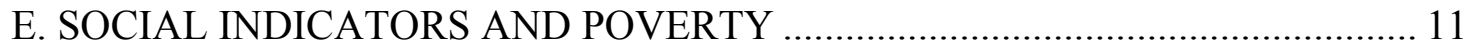

IV. TERMS OF TRADE SHOCKS AND MACROECONOMIC

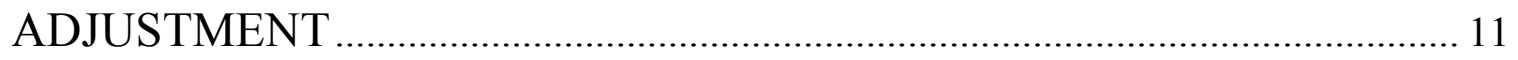

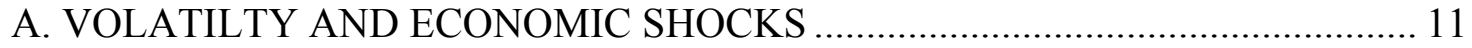

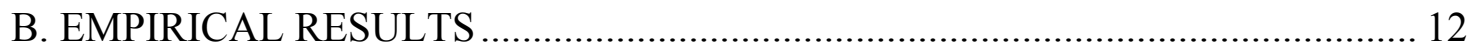

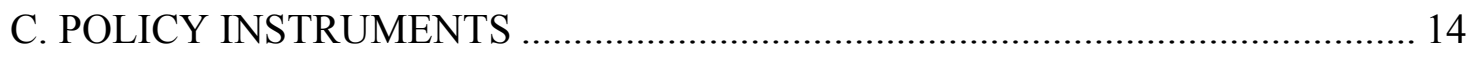

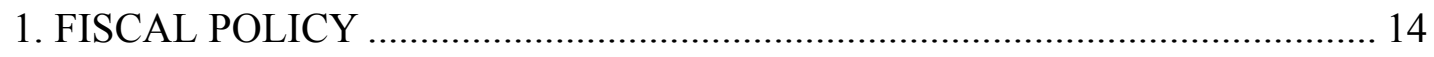

2. MONETARY AND EXCHANGE RATE POLICY ………………………..... 15

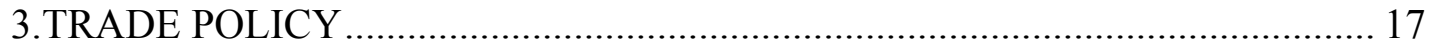

4. WAGE AND LABOR POLICY ………………………............................. 17

5. BORROWING STRATEGY AND EXTERNAL DEBT .................................... 18

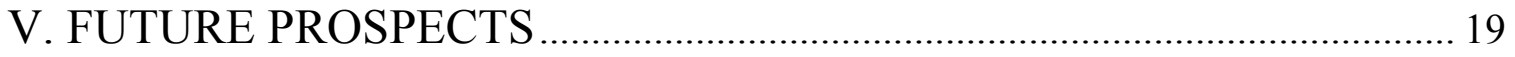




\section{INTRODUCTION}

Volatility has become a prominent and endemic feature of the world economy, and pronounced fluctuations in commodity prices, especially oil, have had a pernicious effect on the macroeconomic performance of many developing countries. The advent of globalization has further accentuated country vulnerability to terms of trade shocks. The management of volatility is especially difficult in oil-exporting countries in the developing world, where output, macroeconomic performance, and fiscal revenue are highly sensitive to minute fluctuations in the international oil price. In many countries, oil price increases lead to expenditure increases, while oil slumps lead to fiscal crises and longer periods in which curtailment of expenditures is difficult to handle. Several analysts have dubbed this the natural resource curse (Gelb and Associates, 1988). Oil economies tend to have booming oil sectors and a stagnant industrial sector as well as lagging exports of other products. Moreover, studies have shown that resource-dependent economies tend to grow more slowly than non-resource-dependent ones at comparable levels of development (IMF, 2002). Natural resource exploration tends to generate high rents and thus the concentration of wealth in one booming sector promotes rent-seeking behavior. In this context, a country's economic success can be gauged by its ability to handle price volatility effectively. The difference between a carefully designed strategy to optimize oil revenues and manage oil windfalls efficiently and an ad hoc short-term approach in which spending reacts to oil market prices will determine the likelihood of a country's economic success in the long-run.

Management of volatility is a critical factor in determining a country's success in responding to terms of trade shocks. While there exist a wide variety of responses to economic shocks and several positive ways to manage volatility, many developing countries, particularly in Africa, have handled commodity-related shocks poorly - by printing money and fueling inflation; overborrowing from commercial banks and multilateral institutions, and leading to spiraling debt; or failing to diversify the export base. The peculiar response of each country has been based on the nature of the macroeconomic shocks, the monetary and exchange rate regime, the policy climate, and most importantly, the domestic political economy in each country.

This paper assesses Gabon's adjustment and response to macroeconomic shocks in 19802000 using a quantitative methodology developed by senior researchers at the World Bank and the IMF (McCarthy, Neary, and Zanalda, 1994; Kochar, 1996; Chami, 2000). Essentially, the studies provide a quantitative decomposition of terms of trade shocks in four performance measures: import intensity, economic compression, export promotion, and changes in external debt levels (residual). While a wide range of policy instruments may affect the performance measures, the measures themselves provide a relatively rigorous way of estimating the nature of adjustment in the economy. Data were obtained from the World Bank and IMF databases, as well as various government and BEAC sources.

A study of Gabon is analytically interesting for several reasons. Firstly, in a time when there is greater international movement toward flexible exchange rates, Gabon is a member of a common currency and trade union with a fixed exchange rate pegged to the euro. While in the mid-1970s, more than 70 percent of developing countries had some type of pegged exchange rate, by 2003, less than half of the countries did. Secondly, it is an oil-rich country that is struggling to adjust to a post-oil world. Careful projections estimate that oil in Gabon will be depleted within the next 10 to 15 years. The nature of its diversification, particularly given its high unit labor costs and wage structure, will be interesting to follow. Thus Gabon is a kind of "trailblazer," in transition to a post-oil economy, a path that will be followed by many other oil economies in the 
next several decades. Thirdly, the country has developed an unenviable record of low productive investment, coupled with poor governance and corruption. Oil mismanagement has been endemic, and social indicators have shown no major improvements since the 1970s. Fourth, it has a medium-term unsustainable debt profile, but being a middle-income country, it is ineligible for debt relief. Thus, for a variety of reasons, Gabon's experience needs to be closely watched.

\section{THEORETICAL MODEL FOR EVALUATION OF POLICY RESPONSES}

The paper applies a theoretical model developed in the early 1990s by World Bank researchers to measure the balance of payments response to external shocks in small, open economies. Drawing on important literature on the theory of distortions and welfare, the model is very effective in analyzing "Dutch disease" societies. The researchers try to understand country reactions in a policy-making context by assessing the extent to which countries respond asymmetrically to terms of trade shocks. Furthermore, they situate their analysis in a world in which current shocks cannot be identified as either permanent or temporary, and in which volatility of the external environment is as much a problem as the magnitude of individual shocks (McCarthy, Neary, and Zanalda (1994)). The model is particularly effective for countries where there is a fixed exchange rate since one is certain the movements in the exchange rate are not responsible for the variations in trade flows.

The model is essentially a two-period one, with the convention that the lower-case and upper-case variables refer to the first and second period, respectively, while bold variables refer to both periods together. The future price vector is expressed in present value terms, while future spot prices are denoted by $\mathrm{p}_{2}$. Assuming that domestic agents can borrow or lend at the world interest rate, the outcome of utility maximization by the aggregate consumer can be characterized in terms of a two-period expenditure function, e $(p, u)$, where $u$ is the consumer's lifetime utility. The value of GNP in each period is given by a GNP function, which has as its arguments domestic consumer prices, $p$, the world price, and the constrained sales level of an export good not consumed at home, $\mathrm{q}^{*}$, and $\mathrm{x}$, and the level of employment, 1 . Over the two periods, investment I is chosen optimally to maximize the present value of production, denoted by a twoperiod GDP function, g:

(1) $g\left(p, q^{*}, x, l\right)=\operatorname{Max}_{I}\left(g\left(p, q^{*}, x, l\right)-p_{I} I+G\left(P, Q^{*}, X, L, I\right)\right)$

The current balance of payments deficit is therefore given by the following:

(2) $b=e(p, u)+p_{I} I(P, X, L)-g\left(p, q^{*}, x, l\right)+y-f$

In this equation, $y$ is the parameter representing current government expenditure (net of tax revenue) on traded goods, and $\mathrm{f}$ is an exogenous transfer from abroad. The equation shows that the balance-of-payments deficit equals absorption (consumption plus investment) minus GNP (or investment minus savings) plus the government deficit less net international transfers. The specification of the McCarthy, Neary, and Zanalda model is completed by the assumption that the level of employment in each period is determined endogenously in the face of exogenously given wages, $w$ and $\mathrm{W}$. Under these assumptions, the effects of external shocks and policy changes on the current balance-of-payments deficit may be obtained by differentiating equation (2):

(3) $d b=\alpha_{1} d p *+\alpha_{2} d q *+\alpha_{3} d x+a_{4} d f$ 


$$
\begin{aligned}
& +\beta_{1} d P^{*}+\beta_{2} d Q^{*}+\beta_{3} d X+\beta_{4} d F \\
& +\chi_{1} d \gamma+\chi_{2} d w+\chi_{3} d W
\end{aligned}
$$

In this model, the $\alpha$ coefficients give the effects of temporary external shocks while the $\beta$ coefficients give the effects of anticipated future shocks. The sum $\alpha_{1}+\beta_{1}$ gives the effects of anticipated future shocks. Equation 3 provides a measure of all effects on the balance of payments, including current exogenous factors (the first four terms) and future factors (the second set of terms). The last line contains a parameter $\chi$, representing changes in domestic current government expenditures, while the last two terms are domestic wage level changes present and future. Also, it is important to note that Ricardian equivalence is assumed. Finally, given that the magnitude and effects of exogenous shocks depend crucially on future expectations, McCarthy, Neary, and Zanalda argue that specifying and estimating a formal econometric version of equation (3) is infeasible.

Thus, their approach decomposes the various policy responses to external shocks (changes in prices of exports and imports, as well as interest rate changes) in terms of four performance measures: import intensity, economic compression, export promotion, and external debt changes (a residual item). The interesting part of the methodology is that the role of policy instruments in addressing the changes in the balance of payments is not computed directly but rather is the estimated consequence of certain policy actions. Thus, the performance measures give a broad indication of the adjustment undertaken in each country, but one must interpret the results of the decomposition in line with the government's fiscal, wage, monetary and exchange rate, trade, and debt policies in order to get a more precise handle on the country's response to adverse movements in terms of trade. In a very useful paper, Chami (1999) has extended the methodology for Oman, a prominent oil-exporting country, and reaches a variety of interesting conclusions on the role of countercyclical fiscal policy in shielding that economy from adverse shocks. The variables in the analysis are defined as follows: ${ }^{1}$

1)Terms of Trade Effect. This represents the difference between the import effects resulting from changes in the import prices and export effects rising from changes in the export prices. Essentially, this measures the overall impact on balance of payments due to changes in the terms of trade based on variations in both the price and quantity of the exports and imports each year.

2)Import intensity. This measures the change in imports due to changes in import elasticity, assuming no changes in the growth rate. This measure uses an import elasticity, derived econometrically by regressing the logarithm of imports on the logarithm of GDP over the 19802000 period and using OLS estimation, to determine the deviation of actual imports from a hypothetical path with a constant income elasticity. If import intensification takes place, a country's imports are higher than expected.

3)Economic compression. This measures the effect on imports due to a slowdown in the economic growth rate and is computed on the assumption that the elasticity of imports with respect to GDP does not change. Using a trend growth rate determined econometrically, the measure is determined by measuring the difference between actual output and the trend output and then multiplies these by this by the share of imports with respect to GDP. The economic compression is a measure of the effect of change in the growth rate alone and does not include the effect of changes in elasticity.

\footnotetext{
${ }^{1}$ The precise formulas for obtaining the estimates are given in the Technical Appendix.
} 
4)Export promotion. This measure compares the growth in a country's exports by volume in comparison with world export growth. In order to have quantitative evidence on the development of the non-oil sector, Gabon's non-oil export growth was compared with world export growth, with the difference suggesting the extent of diversification. In this way, it provides a good assessment of export promotion by comparing Gabon's export promotion to world exports.

\section{COUNTRY CONTEXT}

Gabon, an equatorial country in Central Africa, is currently one of the richest countries in Sub-Saharan Africa, having a GDP per capita of close to $\$ 4,000$. Characterized by a stable political climate, an equatorial and coastal location, a small population of only about 1.3 million, and a rich endowment of petroleum and timber, it is better off than many Sub-Saharan African countries (whose GDP per capita is frequently below \$500) and has all the classic ingredients for economic success.

In many ways, it is a country of paradoxes. A highly urbanized country, with more than $80 \%$ of the population living in urban areas, Gabon has one of the world's largest pristine ecosystems and has three-quarters of its surface area covered by dense tropical rainforest. An oilrich country with petroleum set to dramatically decline within the next few years, Gabon is an economy with little industrial or agricultural diversification. It imports about $90 \%$ of its food from neighboring countries, and has a weak industrial base. Furthermore, while Gabon has more links with European countries and the US rather than with its African neighbors, it relies on large pools of West African labor to supplement its supply of workers in artisanal, retail, and transport sectors. While it is has considerably high rates of poverty, its capital city, Libreville, ranks as the fourth most expensive city in the world, according to a recent survey (EIU, 2000).

While Gabon has invested vast amounts of resources in transportation infrastructure, due to a combination of difficult topography, improperly targeted public investment, and inadequate maintenance, the current road and rail network of less than $11,000 \mathrm{~km}$ is inadequate to the country's needs. There is no major road connecting the two principal cities, Port-Gentil to Libreville, and the rail network needs rehabilitation. While $\$ 3$ billion was spent in constructing a trans-Gabonese railway in the early 1970s in order to facilitate the export of manganese ore and uranium, the line is underused and poorly maintained.

Its relations with the Bretton Woods institutions and other international donors and creditors have gone through several bumpy phases, in part due to Gabon's occasional difficulties in paying its debt service obligations on a timely basis. In the 1970s and 1980s, donors provided financing for the government's development program. However, disagreements over particular Gabonese investments, especially the Transgabonais railroad, and Gabon's uneven record with regard to the implementation of programs agreed with the Bretton Woods institutions, led to occasional suspension of assistance. However, since the decline in oil has become inevitable, the Gabonese have engaged in substantial fiscal retrenchment. Since 2000, the Gabonese government has taken steps to improve economic performance through a variety of structural reforms, especially through public financial and civil service reform and privatization of several parastatal industries. After a period of macroeconomic surveillance, the IMF is currently assessing the possibility of a one-year Standby Arrangement in the summer of 2004. A three-year Extended Fund Facility (EFF) was shelved because it was felt that the Gabonese did not have a sufficient 
track record in program implementation. Resumption of IMF lending is also important for Gabon since it is a precondition to a rescheduling of debt from the Paris Club of international creditors.

\section{A. ECONOMIC PERFORMANCE: GROWTH}

Gabon's growth performance since independence has been respectable, depending significantly on the performance of the oil sector. From 1965 to 1980, Gabon's GDP growth averaged 9.5\% annually. Gabon has had an annual average per capita GDP growth rate of $2.5 \%$ since 1960. The discovery of offshore oil in 1979 enhanced growth prospects considerably, but the economy contracted in the mid 1980s and from 1987 to 1994 , the economy grew by a small 1.5 percent. From 1995 until 1998 , the economy grew at 4.5 percent annually but suffered a stagnation in 1998 and a sharp contraction of -8.9 percent in 1999. These fluctuations were almost entirely due to the swings in the oil price, on which Gabon's economy is heavily reliant. By the beginning of 2002, the decline in oil production was evident as the economy's growth rate was zero. A

CHART 1: REAL GDP GROWTH IN GABON 1970. $2003(\%)$

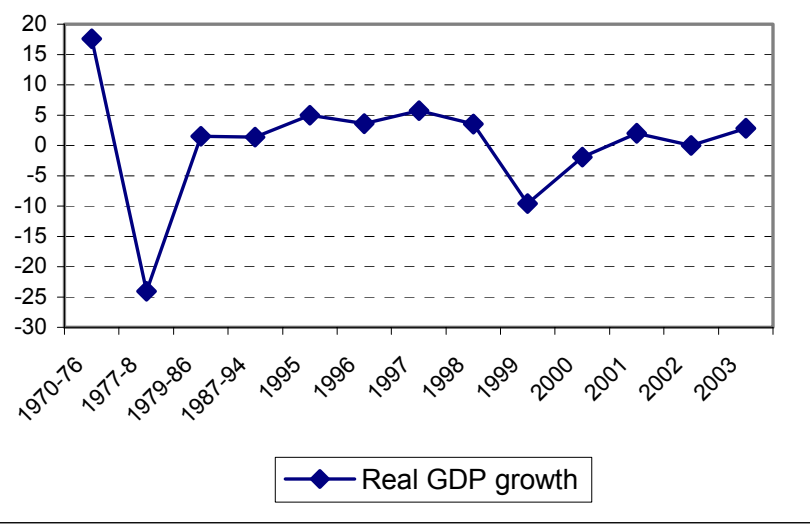
recovery in 2003 fuelled by rising oil prices led to a 2.8 percent increase in the growth rate. Interestingly, while the other countries of the CFA zone benefited greatly from the 1994 devaluation of the CFA franc, Gabon's economic performance was relatively unaffected (except for the timber sector) since most of its revenue comes from the export of primary resources at international prices denominated in dollars.

\section{B. IMPORTANCE OF OIL}

Oil is Gabon's key economic sector and the principal driving force of Gabon's economic growth. Discovered in the late 1970s, oil became the principal export of the country and a source of spectacular windfalls as well as the critical backbone of the economy, leading the country through several boom-bust cycles, with booms in 1974-78 and 1982-1985 followed by strong slumps. Its rich petroleum reserves have historically accounted for close to half of GDP, more than $80 \%$ of its export receipts and $65 \%$ of its tax revenues. For many years, Gabon was Africa's third largest oil producer after Nigeria and Angola, and had the third largest reserves with close to two billion barrels. Since the country has no domestic oil companies, exploration and production is in the hands of foreign multinationals.

Over time the government has restructured the types of agreements with the companies involved. Before 1982, the government gave very generous concessions to the foreign firms, but after 1982, new legislation was enacted that provided increasingly tough terms for the foreign investor by making production-sharing agreements increasingly favorable to the government (de Mowbray, 1991). While under the older legislation, the companies paid the government royalties of 20 percent, under the new system, all crude oil produced was shared between the government and the producing company according the stipulations of the individual contract signed. More than forty multinationals, ranging from Elf and Shell to Amoco, have established core operations there. In order to develop its industry, the country imports considerable oil prospecting and 
drilling equipment from abroad. The US is Gabon's principal oil importer, purchasing more than $\$ 2$ billion in 2000, and Europe and the United States are principal suppliers of material and capital for the oil industry. Gabon has played a role in the international oil market, but recently that has declined. While Gabon was a member of OPEC, in 1996 it left the organization due to the high annual dues.

However, since 1997, Gabon has been facing the dramatic prospect of a gradual decline in oil output because its current oil fields are aging and despite government and foreign investment in new exploration, so far no new large oil fields have been discovered. While some marginal discoveries in recent years have pushed back the oil frontier a few years, the long-term decline is inevitable. Output projections by oil companies and international donors suggest that oil production will halve from 13 million tons in 2001 to 6 million tons in 2007. In order to try to maintain production levels into the future, the government has been actively encouraging foreign investment and attempted to keep production at a level of approximately 350,000 bpd until it can find new investors to bring oil on stream in 2003 and 2004. While oil has historically been a capital-intensive enclave sector, with little impact on the real sector and a low employment absorption, the government has realized the painful internal adjustments are necessary.

In a certain sense, Gabon may define the future trajectory of some of its CEMAC neighbors who have recently discovered oil. Accounting for more than 50 percent of the GDP of Equatorial Guinea and the Republic of Congo and close to 10 percent of Cameroon's GDP, oil accounts for close to 25 percent of CEMAC's total GDP and 70 percent of CEMAC's exports. The experience of Equatorial Guinea, Gabon's neighbor, which became one of the world's fastest growing economies producing 250,000 barrels per day since the discovery of large oil and gas deposits of the island of Bioko in the mid-1990's, and Chad, one of the poorest economies in Africa, but where the discovery and oil reserves and the construction of the billion dollar Cameroon-Chad pipeline will bring much needed public revenue in foreign exchange, may parallel that of Gabon.

\section{DUTCH DISEASE AND THE RENTIER STATE}

A major consequence of the oil boom in Gabon has been the Dutch disease, the deindustrialization of a country's economy occurring when the sudden discovery of natural resource (or a large inflow of foreign currency) induces an export boom and causes an appreciation in the country's currency and hence, adversely affects the competitiveness of a country's manufacturing and agricultural goods. This phenomenon, observed in the Netherlands in the 1970s) in which a boom in one traded goods sector leads to an increase in national incomes as more foreign money flows in and then paradoxically, leads to a decline in the other traded goods sectors (known as the "lagging" traded sector) due to a combination of real exchange rate appreciation and increased production costs, has the paradoxical effect of decreasing exports in other sectors and increasing in imports. Furthermore, resource transfers, mostly capital, shift to the production of domestic non-traded goods to meet growing domestic demand and hence further weaken production in the non-oil tradable sector. Gabon is one of the major examples of the Dutch disease in Africa as well as an example of the fiscal indiscipline that results from oil booms. In 1970, before the major oil boom, manufacturing (mining) accounted for more than 30 percent of GDP, agriculture accounted for 18 percent and oil was only about 26 percent. However, by 1990, the share of agriculture had declined to 7 percent of GDP, while that of mining fell to 5 percent of GDP, while oil contributed close to half of GDP. Thus, as a result of increasing capital flowing to the oil sector, the agriculture and mining sectors contracted over the period from 1960 to 2000. The oil economy operated in an enclave, depending on foreign capital 
while not absorbing much local employment. Meanwhile, a combination of high salaries in the oil sector and a high cost of services, coupled with a small domestic market hindered the diversification of the economy. A nation which was once self-sufficient in food production became dependent on imports for over 80 percent of its food needs, while the manganese and uranium subsectors, the main products of the industrialized mining sector, have contracted over time. In sum, the oilinduced contraction in the non-oil export sector was significant, while the oil boom resulted in an inflation of wage costs in the economy, further weakening the competitiveness of other sectors.

In many ways, Gabon is a classic

CHART 2: DUTCH DISEASE COMES TO GABON - SECTORAL CONTRIBUTION TO GDP 1960-2000 (\%)

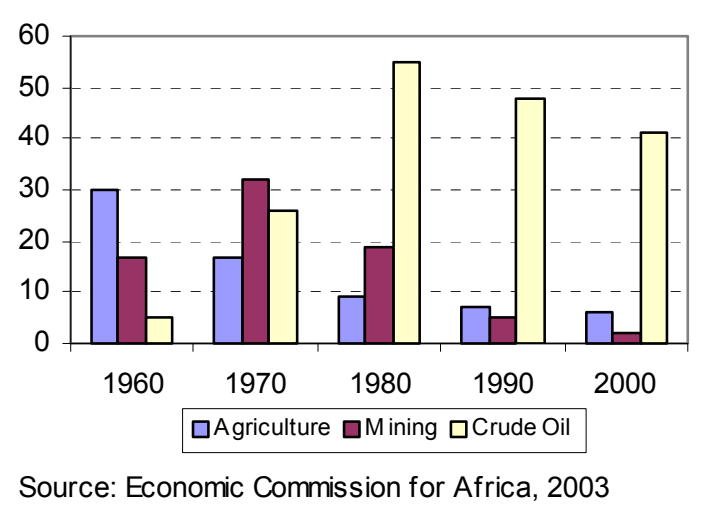

"rentier state," defined in the political science literature as a state reliant not on domestic resource mobilization or extraction of the domestic population's production, but on externally generated revenues and oil rents (Yates, 1996). In such a system, the state generates a large portion of its wealth from extractive industries and natural resources, all sources of "unearned" income and does not develop a long-term productive outlook. As a result of the predominance of oil rents, a domestic political elite has emerged based on the capture of these windfalls. The implications of this are that predatory behavior in the form of short-term profit maximization replaces a longerterm investment strategy. Like in other rentier societies, such as Kuwait, Saudi Arabia, and Venezuela, economic diversification proceeds at a very limited pace.

\section{REGIONAL CONTEXT: CEMAC MEMBER}

In terms of regional context, Gabon has been one of the main members of the Central Africa CFA Zone, CEMAC (Communauté Economique et Monetaire de l'Afrique Centrale), one of the important regional groupings in Africa and consisting of Cameroon, Central African Republic, Chad, Congo (Brazzaville), Equatorial Guinea, and Gabon. A product of prewar French colonial rule, the six-country grouping forged closer monetary and economic integration between its member states in the 1990s, especially after the 1994 devaluation. Essentially a merger of a currency union and a monetary union, the grouping has also developed a system of macroeconomic convergence and multilateral surveillance modeled on the European Union. All countries in the union have a trade regime with a common external tariff (CET), an identical currency pegged to the euro (formerly to the franc), and a common central bank (BEAC) to which monetary policy has been relinquished by the national governments. A distinctive feature of BEAC is the Operations Account with the French Treasury, which helps the central banks to maintain the fixed parity and which was governed by rules set out in monetary accords with France. Since 1994, there has been a reform of regional institutions through the overhaul of the trade regime, strengthening the central bank, elaboration of a set of convergence criteria, and the establishment of a regional umbrella organization.

Gabon's membership in this grouping confers it the advantages of being a member of a stable currency, monetary, and trade regime as well as greater efficiency in bilateral relations with its neighbors. The presence of the independent regional Bank and the set of rules of monetary and 
fiscal discipline designed to reduce the risk and the strictures on financing deficits vis a vis the Central Bank has contributed to low inflation in Gabon and prevented Gabon from monetizing its deficits through printing of money. While in many ways the CEMAC zone is not an optimal currency area - due to the fact that the countries are not natural trading partners and have very different economic structures- regional integration has allowed Central African countries to coordinate their exchange rate policies through the common currency mechanism and prevented the economic uncertainty that arises from exchange rate variability. Secondly, capital and labor mobility, although imperfect, have been better than the norms in other African regions. Finally, regional integration has provided an important source of enhanced growth and economic efficiency by locking Gabon and other Central African countries into policy reform and providing a forum for ensuring country compliance with regional norms. In other words, there exists a strong institutional and historic base - a working monetary and customs union, a system of macroeconomic convergence and surveillance, and a reasonably sound financial sector - through which structural reforms can take place.

\section{E. SOCIAL INDICATORS AND POVERTY}

Despite its rich natural resource endowment, Gabon's poverty incidence and social indicators have not been significantly different from other Sub-Saharan African countries. A World Bank poverty study in 1994 found that the proportion of the population living in extreme poverty remained high and that over 60 percent of the population lived in relative poverty. Income distribution has remained skewed in favor of a small urban elite. In rural areas, falling international commodity prices, coupled with low investment in agriculture, have resulted in poor revenues of farmers. High economic growth has not had a visible impact on poverty indicators, and the contribution of oil and forestry sector revenues to the population as a whole appears quite questionable. The infant mortality rate is relatively high, at 89 per 1000, in close parallel with Cameroon and Ivory Coast. Life expectancy is close to 53 years, and only $66 \%$ of the population has access to drinking water. Forty-one percent of the population is below 15 years of age. HIV AIDS prevalence rate is $4 \%$, significantly lower than its Central African neighbors, but at a critical threshold nevertheless. Educational indicators, however, are relatively higher than the Sub-Saharan average, with literacy at close to $70 \%$. Overall, Gabon's social indicators are weak, especially in comparison to its resource base.

\section{TERMS OF TRADE SHOCKS AND MACROECONOMIC ADJUSTMENT}

\section{A. VOLATILTY AND ECONOMIC SHOCKS}

Shocks and macroeconomic volatility have been staple features of the international economic system, especially in the wake of globalized trade and financial regimes. Thus, adverse movements in terms of trade, commodity prices, or capital flows have a major impact on the stability and growth of developing economies. Moreover, macroeconomic shocks have pronounced effects on country employment and output as well as on investment and income distribution. Terms of trade shocks, such as the long-term slump in the coffee market, the oil price increases in the 1970s and 1980s, the decline and volatility of cotton prices, have all had a strong impact on macroeconomic performance in many developing countries. However, different regions of the world have traditionally experienced varying macroeconomic shocks. Latin American countries have had to deal with high inflation, sluggish growth, and serious external 
disequilibrium, while East Asian countries in the 1990's had to deal with the adverse consequences of financial market volatility. African countries historically have had to manage the volatility and long-term decline in commodity prices as well as temporary shocks in the oil market.

The reaction to macroeconomic shocks depends on the institutional structure of the country, the monetary and exchange rate regime, the policy climate, and the domestic political economy. In fact, there are a wide variety of responses to economic shocks and multiple ways to manage volatility, some having a more positive impact on a country's long-run growth path, while others are more pernicious in nature. Many analysts have argued that African countries' handling of terms of trade shocks has been very poor and has been an important factor in explaining Africa's debt problem. Furthermore, the response of a country varies according to the nature and duration of the shock. In important empirical work at the IMF, Cashin and Pattillo (2000) find that there are marked differences in the typical duration of terms of trade shocks in Sub-Saharan Africa, with half the African countries experiencing short-lived terms of trade shocks, while one-third of countries experience permanent shocks, and that the speed of reversion has important implications for the desirability of financing, rather than adjustment to, terms of trade shocks. Both Sub-Saharan countries with long-lived negative shocks mistakenly perceived as temporary, and countries with short-lived positive shocks mistakenly perceived as permanent undertook excessive external borrowing, especially in the 1970s and 1980s, without changing their economic fundamentals and investing productively in growth areas.

\section{B. EMPIRICAL RESULTS}

The decomposition exercise for Gabon yields a very interesting series of estimates for each of the four critical performance measures. From 1981 to 1986, there was a cumulative decline in the terms of trade position of close to $38.5 \%$ of GDP. From 1982 to 1986, there was a collapse in the oil market as international oil prices fell from $\$ 32$ a barrel to $\$ 14$ a barrel. Government expenditure continued to rise during the period from close to 30 percent of GDP in the early 1980 s to a striking 50 percent by 1986 . The import intensity failed to adjust downward as imports of capital goods to finance the investment boom were significantly higher than expected by the model, cumulatively adding to 5.3 percent of GDP. Moreover, there were minor changes in economic compression and non-oil export promotion, accounting for less than 1 percent of GDP. Thus, there was no macroeconomic adjustment during this period as the government resorted to borrowing heavily from the international commercial markets and bilateral donors, at relatively high interest rates and for shorter maturities of less than 10 years. From 1983 to 1986, the external debt stock of the country increased from $\$ 680$ million to $\$ 1,430$ million, reflecting the use of foreign capital to pay for an ambitious public investment program in Gabon. Public investment, which had taken off in the mid-1970s in the wake of the first OPECinduced oil boom, continued unabated during this period, and there was some evidence that the economy was becoming overheated.

From 1987 to 1990, there was a favorable terms of trade impact due to the increase in oil prices from $\$ 14$ per barrel in 1986 to $\$ 23$ per barrel in 1990 . There was a positive impact on import intensity, amounting to close to 9 percent of GDP. The reasons why imports were lower than expected was due to the reduction of imports of equipment, machinery, and other capital goods for the public investment and engineering projects undertaken by the Gabonese state in the late 1970s and early 1980s as well as the economic recession in the zone. The most notable of these was the construction of the Transgabon Railway, which was envisaged to provide sea 
access to the mineral rich areas of Franceville, and which started in 1973 and completed in 1987 at a cost considerably higher than envisaged. After these projects had been completed, imports adjusted to their levels before the public investment boom. Moreover, during this period, there was a slight reduction in economic compression of close to 2 percent of GDP due to higher GDP growth rates. As in the earlier period, non-oil export promotion was negligible. A stabilization plan with the IMF and agreements with the Paris Club on debt rescheduling had some impact on improving the government's public finance policies.

TABLE 1: TERMS OF TRADE SHOCKS AND ADJUSTMENTS (As a percentage of GDP)

\begin{tabular}{lccccc}
\hline Period & $\begin{array}{c}\text { Terms of trade } \\
\text { shocks/1 }\end{array}$ & $\begin{array}{c}\text { Change in import } \\
\text { intensity/2 }\end{array}$ & $\begin{array}{c}\text { Change in economic } \\
\text { compression/3 }\end{array}$ & $\begin{array}{c}\text { Change in non-oil } \\
\text { export promotion/4 }\end{array}$ & Borrowing/5 \\
\hline Cumulative & & & & & \\
$1981-1986$ & 38.50 & -5.29 & -0.80 & 0.40 & 44.19 \\
$1987-1990$ & -9.60 & 8.49 & -1.50 & -0.34 & -16.25 \\
$1991-1995$ & 8.60 & 0.75 & 0.42 & 0.10 & 7.33 \\
$1996-2000$ & 16.50 & 2.79 & -0.90 & 5.40 & 9.21 \\
& & & & & \\
Averages & & & & & \\
$1981-1986$ & 6.42 & -0.88 & -0.13 & 0.07 & 7.37 \\
$1987-1990$ & -1.92 & 1.70 & -0.30 & -0.07 & -3.25 \\
$1991-1995$ & 1.72 & 0.15 & 0.08 & 0.02 & 1.47 \\
$1996-2000$ & 3.30 & 0.56 & -0.18 & 1.08 & 1.84 \\
\hline
\end{tabular}

Source: Data from IMF, World bank databases, Gabon Ministry of Finance

Definitions from McCarthy, Neary, and Zanalda (1994), Chami (1999)

1/ Positive values means an unfavorable terms of trade shock, while a negative value means a favorable shock.

2/ Negative values indicate the imports are higher than expected.

3/ Positive values show that imports would have been higher under the asumption that real GDP had grown at its estimated expected rate.

4/ Positive value implies diversification

5 / Residual term that measures external borrowing or drawing down on reserves.

In the third phase, from 1991 to 1995, adverse terms of trade shocks of close to 9 percent of GDP affected the Gabonese economy. The response to this shock was a slight increase in import intensity of close to 1 percent of GDP, an increase in economic compression of half a percent of GDP, and an insignificant increase in export promotion. What was needed was a combination of expenditure switching to alter relative prices and shift demand and resources toward the production of tradable goods and expenditure-reducing policies to reduce domestic absorption and increase domestic savings. Due to Gabon's membership in the CEMAC Zone, exchange rate adjustment was not an option, although devaluation was finally implemented only in 1994. As in other countries in the subregion, the internal adjustment strategy was a failure. The situation was difficult among the six countries in the CEMAC zone, whose regional average per capita GDP's fell by 3.9\% annually between 1985 and 1993 and a decline of regional GDP by more than $30 \%$ over this nine year period. The government of Gabon "adjusted" by borrowing from commercial banks and other creditors and by pursuing a policy of internal adjustment through deflation.

In the final phase, from 1996 to 2000, there was another significant cumulative decline in the terms of trade position of 16.2 percent of GDP due to a decrease in the oil price. In response, 
import intensity declined by 2.8 percent of GDP, while non-oil export growth increased by close to $6 \%$ of GDP, and borrowing increased by close to 10 percent of GDP. Economic compression registered a decline of almost 1 percent due to higher than normal non-oil GDP growth. During this period, the country was undergoing significant reform and public financial retrenchment (except for the catastrophic year of 1998 when total expenditure reached close to 50 percent of GDP). The general perception among leading policymakers was that oil was in a state of permanent decline and the government needed to diversify exports and reform the public finance system. Furthermore, large primary surpluses were needed to service the interest payments on the growing public debt. While the adjustment has not been deep enough, this final phase marks a departure from Gabon's past performance.

\section{POLICY INSTRUMENTS}

\section{FISCAL POLICY}

Fiscal policy has been the central tool for Gabonese policymakers to manage the volatility in the economy due to oil shocks. However, for a multiplicity of economic and structural reasons, fiscal policy has not played its required role of restoring macroeconomic equilibrium after exogenous shocks. Empirical work at the International Monetary Fund (IMF) shows that Gabon's overall fiscal stance has largely been procyclical, which has limited the stabilization role of fiscal policy. ${ }^{2}$ Dubbed the "ratchet effect," spending generally increased during oil booms but failed to decrease during oil slumps. In many ways, fiscal policy has acted as a shock multiplier rather than a shock absorber, worsening the impact of a terms of trade shock. While Gabon has historically been a country that has had budget surpluses, the bulk of government revenue has depended on the vicissitudes

CHART 3: PROCYCLICALITY OF GABON'S FISCAL POLICY (\% OF GDP)

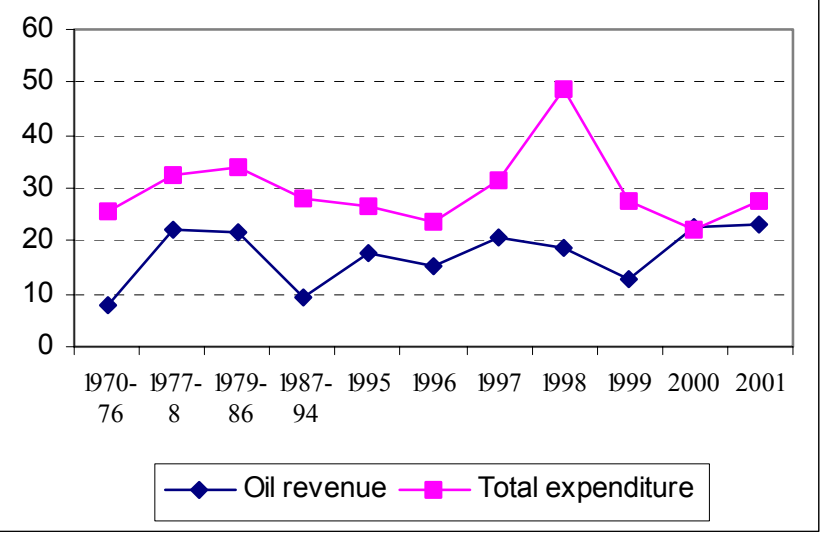
in the oil sector, and the development of non-oil revenue has been relatively weak, until recently. Due to poor tax administration and the weakness in mobilizing the VAT, Gabon's fiscal base has remained overly dependent on oil.

While the terms of trade of trade registered a large shock due to the collapse in oil prices from 1982 to 1986, fiscal policy remained expansionary as the government continued to undertake large public investment. As was the case in previous periods in Gabon's history, fiscal adjustments during oil busts were not immediate. However, from 1987 to 1994, fiscal policy became quite contractionary (as a result of a halving of oil revenue from 1979-1986 to 19871994) as the government scaled back on expenditures, reducing public investment from 18 percent of GDP to 6 percent of GDP from 1987 to 1994 . However, it is important to note that expenditure allocations during this period of internal adjustment translated into a reduction in

\footnotetext{
${ }^{2}$ International Monetary Fund, Gabon: Selected Issues and Statistical Appendix, May, 2002, Washington, DC.
} 
nonwage current expenditure and in public investment, rather than the wage bill, which registered a significant increase during this period. Furthermore, the magnitude of the fiscal adjustment was still insufficient relative to the magnitude of the economic shock that hit Gabon during this period. During this time, fiscal adjustment resulted in an 8.5 percent decline in import intensity.

After the 1994 devaluation, like other countries in the region, Gabon's fiscal performance improved as the country embarked on a reform program. In an attempt to develop better relations with international creditors and as well as converge to the fiscal criteria of the CEMAC economic and monetary union, the government made considerable fiscal adjustments, resulting in a decrease in the public sector wage bill as a percentage of GDP. From 1996 to 2000, fiscal policy was relatively contractionary, except for the huge election-induced slippage in 1998. According to experts at the IMF, the primary balance turned from a deficit of over 6 percent of GDP in 1998 to a surplus of 17 percent in 2000-2001, resulting from a painful adjustment, a sharp reduction in public investment and a freeze in wages and salaries (IMF, 2002). The fiscal adjustment resulted in a 2.5 percent decrease in import intensity, while economic compression improved due to higher than normal non-oil GDP growth as timber and other mineral exports increased (partly explained by the devaluation). Interestingly, Gabon's pattern during the post-devaluation period mirrored that of other CEMAC countries, as average government revenue throughout Central Africa was on an increasing trend, rising from $14.5 \%$ of GDP in 1994 to $22.2 \%$ (excluding grants) in 2001, while strict fiscal management (cuts in government sector wages and some cuts in social expenditures) caused a decline in primary government expenditures from 19.5\% of GDP in 1993 to $15 \%$ of GDP by 2001 .

\section{MONETARY AND EXCHANGE RATE POLICY}

One of the main instruments used by countries to handle macroeconomic shocks and imbalances is monetary and exchange rate policies. The nature of the monetary and exchange rate regime in each country can have a major effect on its response to internal and external shocks. Gabon historically has been an important member of the CEMAC trade and monetary regime, which has maintained a fixed parity between its currency, the CFA franc, and the French franc (replaced by the euro in 2000). The rationale behind this exchange rate regime has been multiple. The fixed exchange rate regime and a common CFA currency area have contributed to overall macroeconomic stability in several ways. Firstly, the regime has provided an institutional mechanism for the coordination of exchange rate policies in Central African member countries and has reduced exchange rate variability. Secondly, the common currency area has allowed countries to be more open to international flows of capital and labor relative to many nations that are not members of an economic union. Thirdly, the fixed exchange rate regime has allowed Gabon to minimize the transactions costs of trading relations with other countries in the zone as well as Europe.

However, one of the key deficiencies of the fixed exchange rate regime has been loss of flexibility in adjusting to external shocks through exchange and monetary policies. In this context, monetary policy has acted an instrument for economic stabilization and has not been used primarily for domestic goals. The only time the exchange rate was actually used to adjust to external shocks has been the 1994 devaluation, which had been viewed as an instrument of last resort in the CEMAC zone. Theoretically, in the fixed exchange rate environment, in order to preserve external balances and maintain competitiveness, a combination of expenditure switching and expenditure reducing policies is generally required to respond to external shocks. Expenditure switching policies (usually in the form of real exchange rate depreciation) to alter relative prices and shift demand and resources toward the production of tradable goods should be 
coupled with expenditure reducing policies (mostly monetary and fiscal) to reduce domestic absorption and increase domestic savings.

Both theoretical literature and a growing body of empirical evidence suggest that flexible exchange rate regimes may help insulate an economy from terms of trade shocks by allowing the currency to have a nominal depreciation. In a seminal piece assessing the effects of a 10 percent decline in the terms of trade in 75 developing countries in Africa, Latin America, Asia, and Eastern Europe from 1973 to 1998, Broda and Tille find that in countries with a fixed exchange rate, the shock led to a decline in GDP of nearly 2 percent after two years, while in countries with a flexible exchange rate, the shock produced only a modest contraction of GDP, about 0.2 percent (Broda and Tille, 2000).

Since flexibility in the exchange rate was not an available policy instrument, Gabon has relied on a combination of "internal" adjustment coupled with outright devaluation. From 1987 to 1994, Gabon, like other CEMAC countries, relied on an "internal" adjustment strategy to adjust to the severe shocks that struck the region, and which involved a tight monetary policy and high real interest rates. The growth in domestic credit was quite low, and the BEAC maintained a very prudent monetary strategy. The essential strategy was to deflate domestic prices to achieve the required depreciation in the real effective exchange rate. This strategy involved a combination of deflationary macroeconomic policies and internal structural reforms. However, the required real depreciation in Gabon, as in other countries, proved to be too large to be accomplished without a nominal devaluation. In 1994, the 50\% devaluation of the CFA franc led to a very significant departure from historic exchange rate policy in the sub-region.

An analysis of the real effective exchange rate (REER) from 1980 to 2001, which is the nominal effective exchange rate adjusted for relative movements in national prices, provides several interesting facts. Since the REER is the exchange rate of the domestic currency vis-à-vis other currencies weighted by their share in either the country's international trade or payments, it is a very useful analytical tool as it provides an indication of a country's aggregate external price competitiveness. While the REER registered a very slight increase between 1981 and 1987, between 1987 and 1993, the REER decreased by $30 \%$, but after the 1994 devaluation,

CHART 4: REAL EFFECTIVE EXCHANGE RATE INDEX
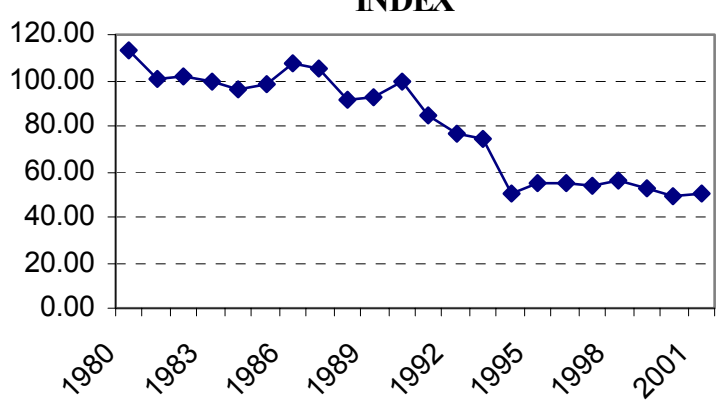

$\neg$ Real Effective Exchange Rate Index the REER fell by 33 percent. During the 1987-1990 period, the exchange rate depreciation and tight monetary policy helped reduce import intensity by close to 9 percent of GDP, but exports failed to respond. After the 1994 devaluation, import intensity increased as the economy experienced economic growth. Since then, the REER has remained essentially flat.

Since the 1994 devaluation, the BEAC has maintained price stability. The member governments of BEAC understood that devaluation could restore competitiveness and macroeconomic stability only if the price level (including wages) did not rise proportionately. They managed to contain the inflationary pressure despite the pessimism that prevailed prior to the devaluation. After experiencing deflation during the 1986-93 depression, Gabon saw average 
consumer prices surge by around 35\% in 1994 and 1995 when the devaluation was being passed through to the prices of imported goods. Tight monetary policy at the BEAC led to a fall in inflation to 3 - $5 \%$ in $1996-97$, a drop to less than $2 \%$ by 2000 .

\section{TRADE POLICY}

Trade policy has been another instrument used by the Gabonese authorities to attempt to strengthen the economy by boosting exports and positioning the country to improve the benefits from globalization, but the payoff has been limited. Historically, Gabon has evolved from being a country with a controlled trade regime to being a member of one of the more open, less protectionist, and less distortionary trade regimes in Sub-Saharan Africa. Beginning in the mid1980 s and accelerating in the 1990s, trade and tariff reform have fundamentally altered the trade regime in Gabon. After the 1994 devaluation, as part of the consolidation of the CEMAC regional integration process of strengthening fiscal and customs reforms, a common external tariff with a four-rate escalating structure was adopted: 5 percent for essential goods; 10 percent for raw materials and capital goods; 20 percent for intermediate goods; and 30 percent for consumer goods. Furthermore, there was a significant dismantling of many of the quantitative restrictions and surcharges that had been used extensively in the 1970s and 1980s. Furthermore, in late 1990s, the country improved the environment for business activity by reforming important aspects of regulation, bringing in a new investment code, and implementing new commercial laws.

However, in spite of these changes, the trade policy did not play a significant role in mitigating the adjustment costs from the terms of trade shocks. For most of the 1980s and 1990s, non-oil export growth was negligible. However, beginning in the second half of the 1990s, limited gains from trade liberalization led to a boost in non-oil exports, most notably timber and manganese, thus contributing to $5.4 \%$ of GDP. Overall, the limited success of trade policy suggests that other factors, such as high unit wage costs and poor infrastructure, may be behind Gabon's limited success in export diversification.

\section{WAGE AND LABOR POLICY}

Wage policy in Gabon has not been a major instrument used by policymakers to adjust to terms of trade shocks. The absence of wage-price flexibility and the presence of large downward nominal wage-price rigidities, which have inhibited adjustments in the relative prices of both tradable and nontradable goods, have had an adverse effect on the overall competitiveness of the country. In this matter, there are two important considerations. Firstly, as is the case in many oilrich "Dutch disease" nations, characterized by lack of diversification and by high unit labor costs, wages have not adjusted to changes in external terms of trade. Secondly, in the CFA exchange rate regime, the absence of labor market and wage-price flexibility has meant that asymmetric shocks have led to real exchange rate misalignment between countries and made it more difficult to be competitive vis a vis neighboring countries.

Although there are severe limitations of labor market data in Gabon, it is possible to formulate a basic story. In the 1980s and 1990s, the country's public sector grew at a rapid rate, giving Gabon one of the highest ratios of public employment to population in the developing world. The wage bill as a percentage of total revenue expanded from 30.2 percent in 1970-76 to 68.6 percent in 1987-1994. It is important to note that during the 1987-1994 depression, the government responded by cutting investment and nonwage expenditure, but left wage expenditure intact. Only by 1996 did the government begin to freeze wages and salaries as the existing 
economic situation became untenable. In 1997-2003, there was a significant retrenchment of the public sector as the country continued its adjustment toward a post-oil world. Furthermore, it is important to note that the minimum professional salary (salaire minimum interprofessionel garanti) in Gabon was significantly higher than in Cameroon, Chad, and the Republic of Congo, hence highlighting Gabon's low competitiveness vis a vis its CEMAC neighbors.

\section{BORROWING STRATEGY AND EXTERNAL DEBT}

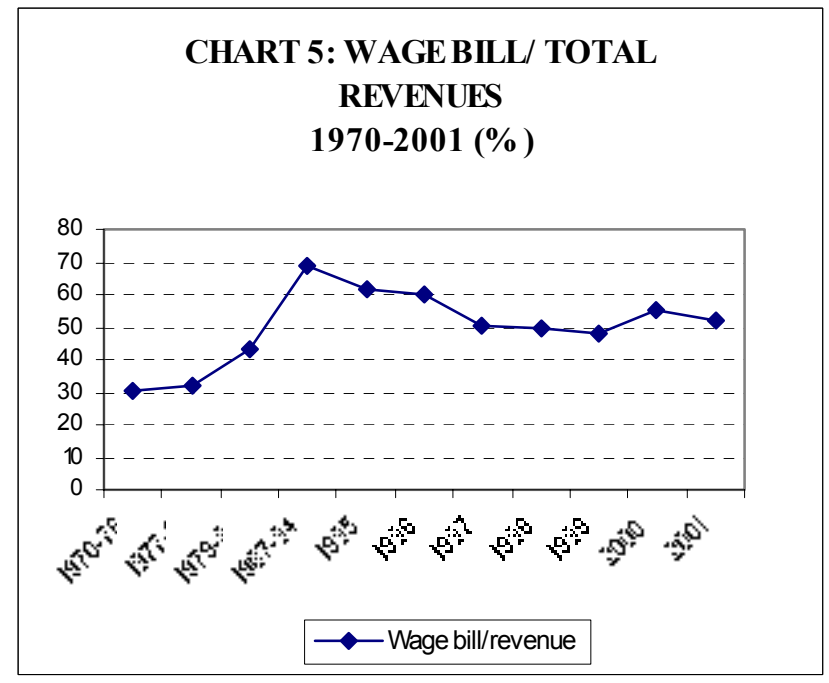

In the 1970s and 1980s, in the wake of the oil boom, Gabon engaged in large borrowing from both private commercial banks and multilateral institutions to finance its public investment programs. Because Gabon is a middle-income country, private creditors lent money to the country at relatively high interest rates with shorter maturities than most SubSaharan African nations. In this way, it postponed much-needed adjustment through foreign borrowing. From 1981 to 1986 , Gabon responded to the oil price shock by increasing its cumulative borrowing (stock) to 44 percent of GDP. From 1970-76 to 1995, Gabon's external debt stock/GDP ratio increased spectacularly from 30 percent of GDP to 75 percent. After a curtailment of borrowing during the painful years of 1987-1990, the country continued to

CHART 6: GABON'S DEBT BUILDUP (\% OF GDP)

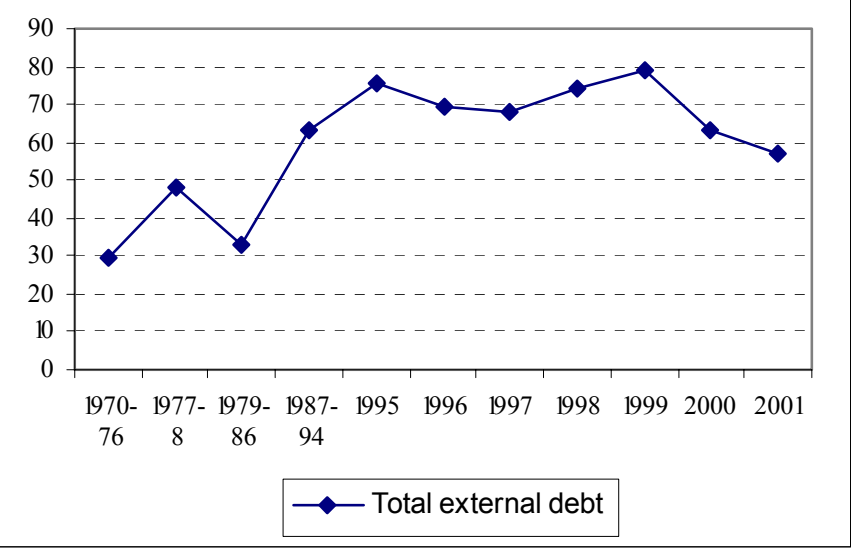

borrow and reschedule existing debt from 1991 to 1995 (7 percent of GDP) and from 1996 to 2000 (9 percent of GDP). After 1999, the government made a concerted effort to reduce the debt and was forced to maintain primary surpluses in order to pay the mounting debt service, currently close to $14 \%$ of GDP and representing more than 40 percent of government revenue. The combination of high medium term debt, which has been deemed as unsustainable by several experts, as well as high interest payments of debt service, has forced the Gabonese government to undertake significant fiscal adjustment. Moreover, the irony of Gabonese development was that the debt was incurred to finance projects and investment programs with very questionable objectives and low rates of return.

Thus, as a result of a poor borrowing strategy and profligate investments, Gabon has a significant external debt burden, estimated at close to $\$ 4$ billion at the end of 2002, and recently 
has had difficulties meeting repayments to the Paris and London Clubs of creditors. ${ }^{3}$ Of its total debt, slightly less than one-fifth is currently owed to the multilaterals. It is important to note that as a middle-income country, Gabon does not qualify for debt relief under the HIPC initiative, even though the country has a considerable debt stock. In 2001, Gabon faced short-term liquidity pressures that caused it to miss a series of loan repayments to banks and other commercial institutions, which partly damaged its financial credibility and caused many ratings agencies to downgrade its sovereign risk status. This has especially been the case with both the commercial creditors of the London Club and the official creditors of the Paris Club. Some of the late and delinquent payments centered around loans that were restructured under the London Club terms as part of the financial maneuverings at the time of the 1994 CFA devaluation, and that amounted to 90 million dollars in 1994. However, from 1999 to 2001, the external debt decreased significantly from 80 percent of GDP to 60 percent as the government sought to curtail its public spending. However, the government has resorted to domestic bank borrowing in order to finance some of its expenditures, with some crowding-out effects on the domestic private sector. In conclusion, throughout the 1980s and early 1990s, Gabon has relied on a strategy of postponing adjustment by borrowing, but the unsustainability of its debt, combined with its difficulty in rescheduling loans, has prompted more drastic fiscal measures in recent years.

\section{FUTURE PROSPECTS}

Gabon's economic performance over the next decade will depend critically on the success of its diversification policies. Given the limitations in exchange rate policy and the relinquishing of monetary policy to the BEAC, conservative fiscal policy, coupled with a strategy to provide incentives to key private businesses, will determine the country's transition toward a post-oil world. In this context, public financial reform and fiscal retrenchment, coupled with measures to develop the non-oil sector, will be paramount for the country. Donor support through technical assistance and policy dialogue will be useful in helping the country manage further terms of trade shocks.

\footnotetext{
${ }^{3}$ In this context, the franc zone has protected the government from the impact of currency fluctuations on its external debt obligations.
} 


\section{REFERENCES}

Broda, Christian and Cedric Tille, "Coping with Terms of Trade Shocks in Developing Countries," Federal Reserve Bank of New York, November, 2003.

Cashin, Paul and Catherine Pattillo, "Terms of Trade Shocks: Are They Short-Lived or LongLived," IMF Working Paper 00/72, Washington, DC, 2000.

Cashin, Paul, John McDermott, and Hong Liang, 1999, "How Persistent Are Shocks to World Commodity Prices?” IMF Working Paper 99/80, Washington, DC, 2000.

De Mowbray, Patricia, "Gabon to 1995: Will Oil Secure Economic Transformation," Economist Intelligence Unit, Special Report No. 2021, London, 1991.

Chami, Saade, "External Shocks, Policy Responses, and Domestic Adjustment," in Oman Beyond the Oil Horizon: Policies toward Sustainable Growth," (edited by Ahsan Mansur and Volker Treichel), International Monetary Fund Occasional Paper 185, Washington, DC, 1999.

Gelb, Alan, "Oil Windfalls: Blessing or Curse,” World Bank research publication, Oxford University Press, 1988.

Hinkle, Larry and Peter Montiel, "Exchange Rate Misalignment: Concepts and Measurements for Developing Countries," World Bank research publication, Oxford University Press, 1999.

Hinkle, Larry et al, "What Lies Ahead for the Two CFA Zones," World Bank, 1997, mimeo.

International Monetary Fund, “Gabon- Staff Reports,” Washington DC, 1998-2003.

International Monetary Fund, International Financial Statistics, 1980-2002, Washington, D.C.

Leite, Carlos and Jens Weidmann, "Does Mother Nature Corrupt? Natural Resources, Corruption, and Economic Growth" International Monetary Fund. Working Paper No. 99/85. July 1, 1999.

McCarthy, Desmond, J.P. Neary, and Giovanni Zanalda, "Measuring the Effects of External Shocks and the Policy Responses to Them: Empirical Methodology Applied to the Philippines," World Bank Policy Research Working Paper 1271, March, 1994.

Soderling, Ludvig, "Escaping the Curse of Oil ? The Case of Gabon, IMF Working Paper No. 0/93, International Monetary Fund, Washington, DC, 2000.

World Bank, World Development Indicators (Electronic Database), 1960-2002, Washington, D.C.

Yates, Douglas, The Rentier State in Africa, Africa World Press, Trenton, NJ, 1996.

Zafar, Ali and Keiko Kubota, "Regional Integration in Central Africa: Key Issues," Africa Region Working Paper Series Number 52, World Bank, June, 2003. 


\section{ANNEX 1: GABON MACROECONOMIC INDICATORS}

TABLE 1: GABON KEY ECONOMIC INDICATORS 1997-2005

\begin{tabular}{|c|c|c|c|c|c|c|c|c|c|}
\hline & 1997 & 1998 & 1999 & 2000 & 2001 & 2002 & $\begin{array}{c}2003 \\
\text { est }\end{array}$ & $\begin{array}{c}2004 \\
\text { proj }\end{array}$ & $\begin{array}{l}2005 \\
\text { proj }\end{array}$ \\
\hline \multicolumn{10}{|l|}{ Macroeconomy } \\
\hline Nominal GDP (bill. CFA francs) & 3109.1 & 2645.0 & 2840.1 & 3618.3 & 3485.5 & 3448.9 & 3520.5 & 3385.8 & 3361.4 \\
\hline Real GDP growth (\%) & 5.7 & 3.5 & -9.6 & -1.9 & 2.0 & 0.0 & 2.8 & 1.1 & 0.8 \\
\hline Oil (\%) & -2.1 & -3.4 & -5.6 & -10.2 & -5.7 & -1.4 & 7.6 & -3.5 & -7.9 \\
\hline Non-oil (\%) & 10.2 & 7.0 & -8.9 & 2.1 & 5.3 & 0.6 & 1.0 & 3.0 & 4.0 \\
\hline Inflation (end of period) (\%) & 2.3 & 2.6 & -0.8 & 1.8 & 1.0 & 2.0 & 2.0 & 2.0 & 2.0 \\
\hline Gross investment/GDP (\%) & 31.5 & 39.1 & 23.9 & 21.8 & 25.8 & 24.4 & 23.9 & 25.8 & 26.0 \\
\hline Gross national savings/GDP (\%) & 34.3 & 20.4 & 15.3 & 28.0 & 26.0 & 25.1 & 22.9 & 19.8 & 19.9 \\
\hline \multicolumn{10}{|l|}{ Public Finance } \\
\hline Revenue (excluding grants)/GDP (\%) & 33.1 & 34.5 & 28.7 & 33.6 & 30.8 & 31.5 & 30.2 & 28.3 & 27.0 \\
\hline Total expenditure and net lending/GDP (\%) & 31.5 & 48.5 & 27.5 & 22.0 & 27.6 & 28.1 & 22.8 & 24.4 & 23.7 \\
\hline Primary budget balance/GDP (\%) & 7.8 & -6.3 & 8.1 & 17.5 & 12.0 & 7.9 & 11.5 & 9.0 & 7.4 \\
\hline Overall balance (excluding grants)/GDP (\%) & 1.6 & -14.0 & 1.2 & 11.6 & 3.2 & 3.4 & 7.4 & 3.9 & 3.3 \\
\hline \multicolumn{10}{|l|}{ Trade } \\
\hline Exports, f.o.b. (in billions of CFA) & 1790.5 & 1124.8 & 1550.6 & 2288.5 & 1919.0 & 1878.1 & 1893.3 & 1650.9 & 1424.4 \\
\hline Imports, f.o.b. (in billions of CFA) & -566.3 & -650.7 & -518.1 & -572.8 & -660.6 & -680.7 & -690.2 & -700.3 & -706.5 \\
\hline Current account balance/GDP (\%) & 2.8 & -18.7 & -8.6 & 6.2 & 0.3 & 0.6 & -1.0 & -6.2 & -6.3 \\
\hline \multicolumn{10}{|l|}{ Debt } \\
\hline Stock of debt (\$ million) & 68.2 & 74.4 & 79.2 & 71.2 & 73.7 & 70.3 & 67.4 & 67.0 & 64.7 \\
\hline Debt-service ratio ( $\%$ of revenue) & 11.8 & 14.6 & 13.5 & 20.1 & 41.0 & 13.3 & $\ldots$ & $\ldots$ & $\ldots$ \\
\hline Exchange rate (CFA francs per U.S. dollar) & 583.7 & 590.0 & 614.9 & 710.0 & 732.5 & 695.4 & 580.1 & $\ldots$ & $\ldots$ \\
\hline
\end{tabular}

Sources: Government of Gabon, IMF, and Bank staff estimates 


\section{ANNEX 2: TERMS OF TRADE SHOCKS AND RESPONSES}

TABLE 2: TERMS OF TRADE SHOCKS AND RESPONSES (\% OF GDP)

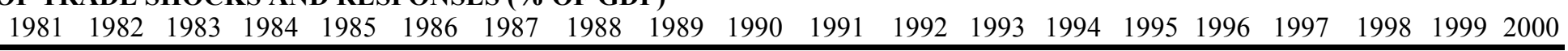

\begin{tabular}{|c|c|c|c|c|c|c|c|c|c|c|c|c|c|c|c|c|c|c|c|c|}
\hline Terms of Trade & -2.9 & 3.6 & 2.8 & 10.0 & 3.1 & 22.1 & -2.1 & -0.4 & 0.5 & -7.6 & 4.8 & 1.3 & 11.5 & -4.3 & -4.8 & -8.4 & 4.9 & 17.6 & 0.1 & 2.4 \\
\hline Import Intensity & -8.6 & 0.7 & 2.2 & -2.7 & 1.3 & 1.8 & 4.9 & -2.5 & 4.5 & 1.7 & -3.6 & 2.2 & -4.8 & 9.2 & -2.3 & -0.1 & -1.2 & -2.5 & 6.6 & -1.0 \\
\hline Econ. Compression & 0.4 & -1.1 & 0.7 & 1.0 & -1.0 & -0.8 & -4.7 & 2.3 & 1.4 & 0.5 & 0.5 & -1.0 & 0.0 & 0.2 & 0.7 & 0.5 & 0.5 & -0.1 & -1.9 & 0.0 \\
\hline Export Promotion & -1.40 & -0.10 & 0.10 & 1.80 & 0.00 & -0.20 & -1.00 & -0.40 & 0.60 & 0.60 & 0.50 & -0.60 & 1.50 & -0.90 & -0.50 & -0.50 & 0.40 & -1.90 & 3.40 & 3.80 \\
\hline
\end{tabular}

Macroeconomic Data

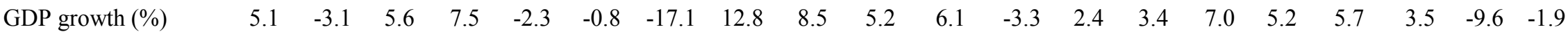

$\begin{array}{lllllllllllllllllllll}\text { REER Index } & 100.4 & 101.3 & 99.7 & 95.7 & 98.6 & 107.4 & 105.5 & 91.2 & 92.2 & 100.0 & 84.6 & 76.4 & 74.1 & 49.9 & 55.1 & 54.5 & 53.7 & 55.5 & 53.1 & 49.5\end{array}$

$\begin{array}{lllllllllllllllllllll}\text { Oil prices (\$/barrel) } & 35.5 & 32.7 & 29.7 & 28.6 & 14.4 & 14.4 & 18.2 & 14.7 & 17.8 & 22.9 & 19.4 & 19.0 & 16.8 & 15.9 & 17.2 & 20.4 & 19.2 & 13.1 & 18.1 & 28.2\end{array}$

$\begin{array}{lllllllllllllllllllll}\text { Merch.exports (bil. \$) } & 1.70 & 1.57 & 1.47 & 1.79 & 2.00 & 1.26 & 1.28 & 1.20 & 1.53 & 2.48 & 2.52 & 2.29 & 2.20 & 2.39 & 2.67 & 3.19 & 3.07 & 1.90 & 2.51 & 3.22\end{array}$

$\begin{array}{lllllllllllllllllllll}\text { Merch. Imports (bil.\$) } & 0.83 & 0.80 & 0.68 & 0.79 & 0.95 & 0.90 & 0.78 & 0.93 & 0.82 & 0.85 & 1.01 & 0.97 & 0.92 & 0.71 & 0.93 & 0.97 & 0.97 & 1.10 & 0.74 & 0.81\end{array}$

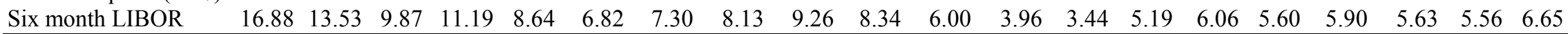

Source: World Bank, IMF, Government of Gabon 

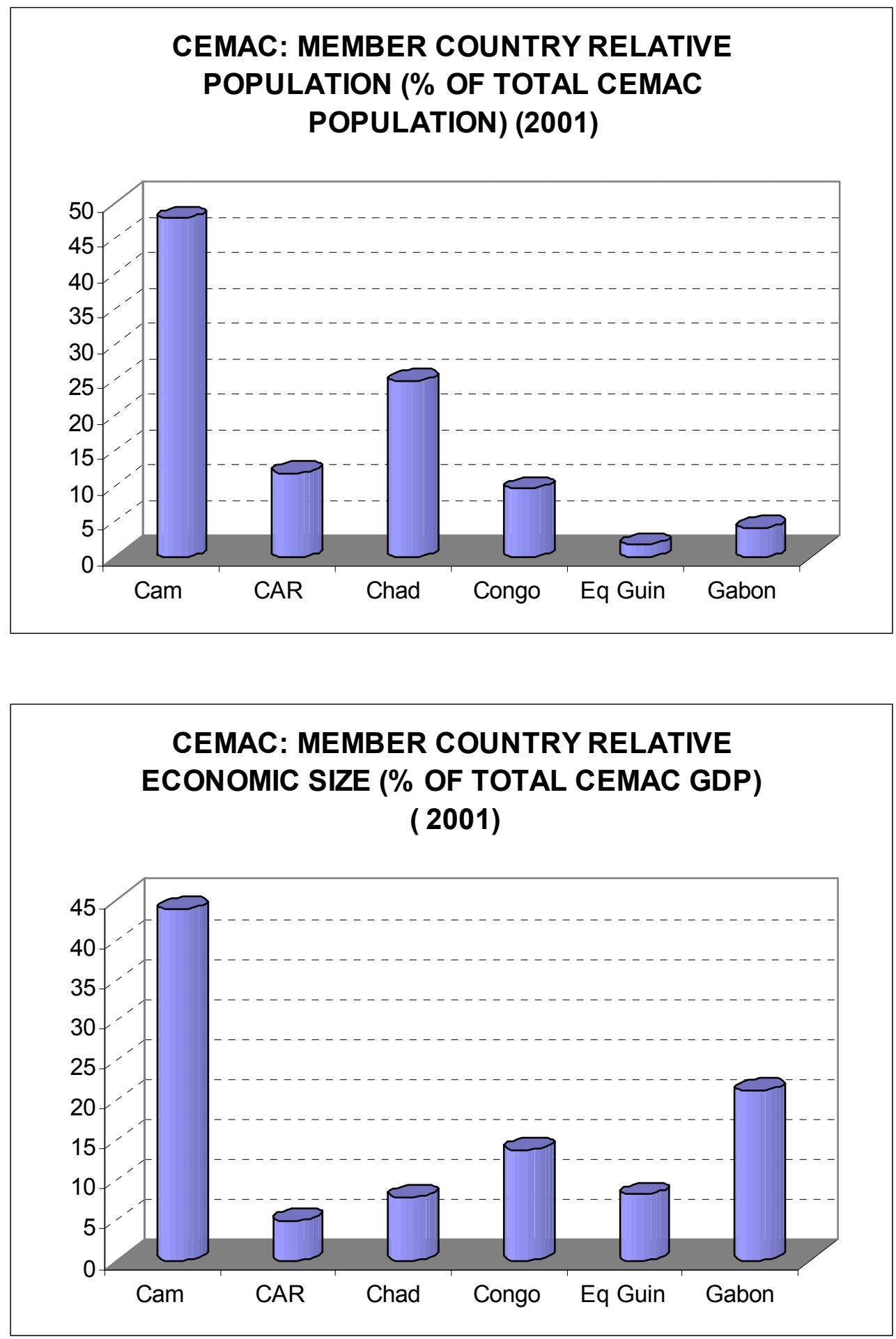

Source: IMF and World Bank databases, 2001 


\section{ANNEX 4: FORESTRY AND OTHER SECTORS IN GABON}

After oil, the forestry sector is Gabon's second largest foreign exchange earner accounting for close to 15 percent of export revenue and is the second largest formal employer after the government sector. Moreover, Gabon is Africa's second largest timber exporter after Cameroon, and its sales of raw wood account for a fifth of its total sales. As a sign of the strength of the sector, the contributions of forestry to export earnings are significantly higher than its 2 percent share of GDP. Heavily forested with about 70 percent of the country covered, Gabon has mostly lowland moist evergreen rainforests comprising an enormous diversity of species with two prized species, okoumé and ozigo, accounting for more than half of Gabon's timber exports. Most of the timber is shipped abroad as unprocessed logs. In the last decade, there has been a major shift in international demand for Gabon's timber with the decline in traditional European markets. While historically the majority of the country's wood exports went to France, in recent years, more than $50 \%$ of the countries exports have gone to East Asia. China, in particular, have become increasingly dependent on Gabonese timber to meet the needs of its burgeoning economy. The forests of Gabon are part of the large Central African rainforest, which covers 190 million hectares, is about a fourth the size of the continental United States, and which represents the second largest eco-forest zone on the planet after the Amazon.

The Société Nationale des Bois du Gabon (SNBG), jointly owned by the state (51\%) and private forestry companies (49\%), has historically had a monopoly on forestry exports but in the last several years, its power has decreased as new companies have entered the lucrative market. While there is a lack of information about the activities of foreign logging companies in Gabon, currently foreign capital plays a large role in the timber industry, and Asian logging companies have established an increasing presence in the area. However, the sector is constrained by a poor transportation network, the absence of a proper regulatory environment, and the presence of timber export taxes.

The role of agriculture in the economy, traditionally an important one in the 1960's and 1970 's, has diminished over time due to domination by the petroleum sector. Once a country selfsufficient in food production and based on subsistence agriculture centered on indigenous food crops like manioc and peanuts as well as cash crops like cocoa and coffee, the country now depends overwhelming on European and American food imports for more than 80 percent of its needs, with cheap wheat imports from the United States are especially common. Low productive investment in agriculture, weak rural infrastructure, the availability of cheap imports, and falling commodity prices have together resulted in a shrinkage of the rural sector over the last thirty years and currently account for less than 7 percent of GDP. For a country that is endowed with such adequate rainfall, arable land and a 800 kilometer coastline, the low share of agriculture and the lack of development in the fisheries sector is noteworthy. (ECA, 2003)

Similarly, Gabon's manufacturing and industrial sector, which makes up 15 percent of nonoil GDP, has remained limited in size. Mining of uranium and manganese has diminished in the wake of the oil boom (and falling international prices) and diversification has proceeded at a limited pace. The weakness of manufacturing can be attributed to the high unit labor costs, the absence of a favorable policy regime, the perverse effects of an overvalued exchanged rate and an oil-based economy, and a poor transport network. Construction, which boomed in the 1970's and 1980s due to the large public investment projects, has suffered in recent years due to the fiscal constraints of the government. Finally the services sector - commerce, tourism, telecommunications, financial and oil services- makes up 35\% of nonoil GDP is another sector which has been overshadowed by the oil sector, but is recently emerging as a potential growth source. 


\section{ANNEX 5: TECHNICAL APPENDIX ELABORATING MCCARTHY, NEARY AND ZANALDA METHODOLOGY}

\section{1) Terms of Trade Effect (TOTT)}

Import and export values, gained or lost by the country as a consequence of changes in the terms of trade, are obtained using the following approach.

$$
\text { TOTT }_{t}=\text { TOTM }_{t}-\text { TOTX }_{t} \quad t=(1980-2000)
$$

$\mathrm{TOTT}_{\mathrm{t}}$ is the net effect of terms of trade variation at time $t$ due to import and export price changes from time $\mathrm{t}-1$ to $\mathrm{t}$. The convention adopted is that unfavourable terms of trade effect $\mathrm{TOTT}_{\mathrm{t}}$ is positive.

\section{Import Effect}

$$
\mathrm{TOTM}_{\mathrm{t}}=\mathrm{VM}_{\mathrm{t}}\left(\mathrm{PM}_{\mathrm{t}}-\mathrm{PM}_{\mathrm{t}-1}\right)
$$

A positive value for TOTM $_{t}$ represents a loss in imports value by the country at time $t$ due to an unfavourable import price change from time $\mathrm{t}-1$ to time $\mathrm{t}$.

$\mathrm{VM}_{\mathrm{t}}=\mathrm{M}_{\mathrm{t}} / \mathrm{PM}_{\mathrm{t}} \quad$ Volume of merchandise imports by the country at time $\mathrm{t}$

$\mathrm{M}_{\mathrm{t}}=$ Value of merchandise imports by the country at time $\mathrm{t}$

$\mathrm{PM}_{\mathrm{t}}=$ Unit value of imports at time $\mathrm{t}$

\section{Export Effect}

$$
\mathrm{TOTX}_{\mathrm{t}}=\mathrm{VE}_{\mathrm{t}}\left(\mathrm{PE}_{\mathrm{t}}-\mathrm{PE}_{\mathrm{t}-1}\right)
$$

A positive value for $\mathrm{TOTX}_{\mathrm{t}}$ represents a gain in exports value by the country at time $\mathrm{t}$ due to an favourable export price change from time $t-1$ to time $t$.

$\mathrm{VM}_{\mathrm{t}}=\mathrm{M}_{\mathrm{t}} / \mathrm{PM}_{\mathrm{t}} \quad$ Volume of merchandise exports by the country at time $\mathrm{t}$

$\mathrm{M}_{\mathrm{t}}=$ Value of merchandise exports by the country at time $\mathrm{t}$

$\mathrm{PM}_{\mathrm{t}}=$ Unit value of exports at time $\mathrm{t}$

Adding together the import and export effects:

TOTT $=\left(\mathrm{VM}_{\mathrm{t}}\left(\mathrm{PM}_{\mathrm{t}}-\mathrm{PM}_{\mathrm{t}-1}\right)\right)-\left(\mathrm{VE}_{\mathrm{t}}\left(\mathrm{PE}_{\mathrm{t}}-\mathrm{PE}_{\mathrm{t}-1}\right)\right)$

A positive $\mathrm{TOTT}_{t}$ is an unfavourable shock. Note that $\mathrm{TOTT}_{t}$ gives the net result for one year. To compute effects over a number of years, these terms may be summed. 


\section{2) Import Intensity (MSUB)}

$\mathrm{MSUB}_{\mathrm{t}}=\mathrm{MH}_{\mathrm{t}}-\mathrm{MA}_{\mathrm{t}} \quad \mathrm{t}=(1980$ to 2000$)$

$\mathrm{MSUB}_{\mathrm{t}}$ is a measure of import intensity computed as follows:

$\mathrm{MH}_{\mathrm{t}}=\mathrm{M}_{\mathrm{t}-1}\left(1+\mathrm{EL}_{\mathrm{t}}\left(\mathrm{GDPGR}_{\mathrm{t}}\right)\right.$

$\mathrm{MH}_{\mathrm{t}}$ is a hypothetical value of imports at time $\mathrm{t}$, assuming the import elasticity to GDP has remained at its "historical" level and that there is no change in price from time t-1 to t.

$E L_{t}$ is the import elasticity to GDP expected at time $t$ based on the previous ten years and computed by regressing

$\log \mathrm{V}=\mathrm{a}+\mathrm{b} \log \mathrm{GDP} \quad \mathrm{b}=\mathrm{EL}$

$\mathrm{V}_{\mathrm{t}}=$ country's import volume index at time $\mathrm{t}$

GDPGR $_{\mathrm{t}}=\left(\mathrm{GDP}_{\mathrm{t}}-\mathrm{GDP}_{\mathrm{t}-1}\right) / \mathrm{GDP}_{\mathrm{t}-1}$ growth rate of country's GDP from time $\mathrm{t}-1$ to $\mathrm{t}$

$\mathrm{MA}_{\mathrm{t}}=\mathrm{M}_{\mathrm{t}-1}\left(1+\mathrm{GRVM}_{\mathrm{t}}\right)$

$\mathrm{MA}_{t}$ is the value of imports at time $t$, if it is assumed that no change in price from time $t-1$ to thas occurred.

$\mathrm{GRVM}_{\mathrm{t}}=\left(\mathrm{VM}_{\mathrm{t}}-\mathrm{VM}_{\mathrm{t}-1}\right) / \mathrm{VM}_{\mathrm{t}-1}$

Substituting,

$\operatorname{MSUB}_{\mathrm{t}}=\mathrm{M}_{\mathrm{t}-1}\left(\mathrm{EL}_{\mathrm{t}}\left(\mathrm{GDPGR}_{\mathrm{t}}-\mathrm{GRVM}_{\mathrm{t}}\right)\right)$

Technological change is partially captured by changes in the elasticity over time.

If import intensification takes place, it means that a country's imports are higher than expected, and therefore, MSUB $_{\mathrm{t}}$ will be negative. 


\section{3) Economic Compression (ECOM)}

$\mathrm{ECOM}_{\mathrm{t}}=\mathrm{MVT}_{\mathrm{t}}-\mathrm{MH}_{\mathrm{t}} \quad \mathrm{t}=(1980$ to 2000$)$

$\mathrm{ECOM}_{\mathrm{t}}$ is a measure of the change in imports at time $\mathrm{t}$ due to compression of the economy.

$\mathrm{MVT}_{\mathrm{t}}=\mathrm{M}_{\mathrm{t}-1}\left(1+\mathrm{EL}_{\mathrm{t}}\left(\mathrm{GDPT}_{\mathrm{t}}\right)\right.$

$E_{t}$ is the import elasticity to GDP expected at time $t$ based on the previous ten years and computed by regressing

$$
\log \mathrm{V}=\mathrm{a}+\mathrm{b} \log \text { GDP } \quad \mathrm{b}=\mathrm{EL}
$$

$\mathrm{GDPT}_{\mathrm{t}}$ is the expected tend growth rate in the country's GDP at time $\mathrm{t}$, based on the previous ten years.

$$
\begin{aligned}
& \log \text { GDP }=a+b t \quad b=G^{-} P_{t} \\
& M_{t}=M_{t-1}\left(1+E L_{t}\left(G D P G R_{t}\right)\right.
\end{aligned}
$$

Substituting,

$$
\mathrm{ECOM}_{\mathrm{t}}=\mathrm{M}_{\mathrm{t}-1}\left(\mathrm{EL}_{\mathrm{t}}\left(\mathrm{GDPT}_{\mathrm{t}}-\mathrm{GDPGR}_{\mathrm{t}}\right)\right)
$$

When economic compression takes place, $\mathrm{ECOM}_{\mathrm{t}}$ assume positive values. Note that $\mathrm{ECOM}_{\mathrm{t}}$ is a measure of the effect of change in the growth rate alone (i.e. does not include the effect of change in elasticity). 


\section{4) Export Promotion (EPR)}

$$
\mathrm{EPR}_{\mathrm{t}}=\mathrm{EA}_{\mathrm{t}}-\mathrm{EH}_{\mathrm{t}} \quad \mathrm{t}=(1980 \text { to } 2000)
$$

$\mathrm{EPR}_{\mathrm{t}}$ provides a measure of export promotion in the country at time $t$, assuming prices have not changed, The difference between growth in the country and world export volumes is sued to gauge the export promotion effort undertaken by the country.

$\mathrm{EA}_{\mathrm{t}}=\mathrm{E}_{\mathrm{t}-1}\left(1+\mathrm{GRVE}_{\mathrm{t}}\right)$

$\mathrm{EA}_{\mathrm{t}}$ is the value of exports at time $\mathrm{t}$, at the price prevailing at time $\mathrm{t}-1$.

$\mathrm{E}_{\mathrm{t}-1}$ is the value of merchandise exports by the country at time $\mathrm{t}-1$ (fob)

$\mathrm{GRVE}_{\mathrm{t}}=\left(\mathrm{VE}_{\mathrm{t}}-\mathrm{VE}_{\mathrm{t}-1}\right) / \mathrm{VE}_{\mathrm{t}-1}$ growth rate of country's GDP from time $\mathrm{t}-1$ to $\mathrm{t}$

$\mathrm{VE}_{\mathrm{t}}=\mathrm{E}_{\mathrm{t}} / \mathrm{PE}_{\mathrm{t}}$

$\mathrm{EH}_{\mathrm{t}}=\mathrm{E}_{\mathrm{t}-1}\left(1+\mathrm{GRXVW}_{\mathrm{t}}\right)$

$\mathrm{EH}_{\mathrm{t}}$ is the value of exports at time $\mathrm{t}$ determined by changes in the volume of world exports, assuming that the price has not changed from time $t-1$ to $t$.

$\mathrm{GRXVW}_{\mathrm{t}}=\left(\mathrm{XVW}_{\mathrm{t}}-\mathrm{XVW}_{\mathrm{t}-1}\right) / \mathrm{XVW}_{\mathrm{t}-1}=$ growth rate of world export volume from time $\mathrm{t}-1$ to $\mathrm{t}$

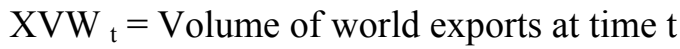

Substituting we obtain:

$$
\mathrm{EPRGR}_{\mathrm{t}}=\mathrm{E}_{\mathrm{t}-1} \quad\left(\mathrm{GRVE}_{\mathrm{t}}-\mathrm{GRXVW}_{\mathrm{t}}\right)
$$

A positive $\mathrm{EPR}_{\mathrm{t}}$ indicates that the country increased its share of world exports. This result might be interpreted as the consequence of an export promotion policy. However, EPR $\mathrm{E}_{t}$ is strongly dependent on changes in international conditions which are independent from domestic policies. 